\title{
Educational intervention to improve adherence to the Mediterranean diet among parents and their children aged 1-2 years. EniM clinical trial
}

\author{
Margarita Roset-Salla ${ }^{1, *}$, Joana Ramon-Cabot ${ }^{1}$, Jordi Salabarnada-Torras ${ }^{1}$, Guillem Pera ${ }^{2}$ \\ and Albert Dalmau ${ }^{2}$ \\ 'La Riera Primary Care Center, Institut Català de la Salut, Ronda Prim 35, Planta 2a, 08302 Mataró, Spain: \\ ${ }^{2}$ Research Support Unit Metropolitana Nord, Institut Universitari de Recerca en Atenció Primària IDIAP Jordi Gol, \\ Santa Coloma de Gramenet, Spain
}

Submitted 11 February 2015: Final revision received 30 April 2015: Accepted 22 June 2015: First published online 10 August 2015

\begin{abstract}
Objective: The objective of the present study was to evaluate the effectiveness of an educational programme on healthy alimentation, carried out in day-care centres and aimed at the parents of children from 1 to 2 years of age, regarding the acquisition of healthy eating habits among themselves and their children.

Design: We performed a multicentre, multidisciplinary, randomized controlled study in a community setting.

Setting: The EniM study (nutritional intervention study among children from Mataró) was performed in twelve day-care centres in Mataró (Spain). Centres were randomized into a control group (CG) and an intervention group (IG). IG received four or five educational workshops on diet, CG did not have workshops.

Subjects: Children, not exclusively breast-fed, from 1 to 2 years of age, in the participating day-care centres and the persons responsible for their alimentation (mother or father).

Results: Thirty-five per cent of the IG did not attend the minimum of three workshops and were excluded. The CG included seventy-four children and seventytwo parents and the IG seventy-five children and sixty-seven parents. Both groups were comparable at baseline. Basal adherence to the Mediterranean diet was $56.4 \%$ in parents (Gerber index) and 7.7 points in children (Kidmed test). At 8 months, Mediterranean diet adherence had improved in the IG by 5.8 points in the Gerber index $(P=0.01)$ and 0.6 points in the Kidmed test $(P=0.02)$ compared with the CG. Conclusions: This educational intervention performed in parents at the key period of incorporation of a 1-2-year-old child to the family table showed significant increases in adherence of the parents to the Mediterranean diet, suggesting future improvement in different indicators of health and an expected influence on the diet of their children.
\end{abstract}

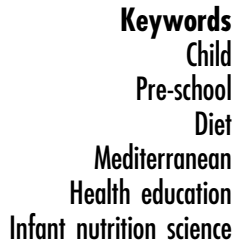

Obesity is a chronic disease of multifactorial origin that has become an important health-care problem because of its associated complications. A progressive increase in the prevalence of obesity has been observed worldwide. In Spain the trend is also alarming, especially among children $^{(1)}$. The global prevalence of overweight and obesity in children of pre-school age $(<5$ years $)$ has risen from $4.2 \%$ in 1990 to $6.7 \%$ in 2010 ( 43 million children). This trend is expected to further increase up to $9 \cdot 1 \%$ in $2020^{(2,3)}$. The problem is accentuated with age. In Spain, the prevalence of overweight and obesity in children aged 6-10 years is $45 \cdot 2 \%{ }^{(4)}$. After 3 years of age, infantile obesity is associated with a greater risk of obesity and an increase in morbidity and mortality in adulthood ${ }^{(5)}$.
Alimentation during infancy is one of the most important factors related to infantile obesity. Parents play a fundamental role in the development of the food preferences of their children ${ }^{(6)}$, not only by the foods they give them but also through their own lifestyles and alimentation $^{(7)}$. Indeed, the learning of dietary habits is particularly important during the first years of life ${ }^{(8)}$. During the first 6 months of life, the energy and nutritional needs of a child are satisfactorily covered by maternal or formula milk. Thereafter, it is necessary to progressively incorporate new foods with quantities adequate for the child's growth until the child becomes familiarized with the family diet at the end of the first year of life. Children learn what, when and how to eat at 9-21 months of life. 
It is at this stage that they begin to acquire the dietary habits that will last until adulthood and will influence their health during their lifetime ${ }^{(9)}$.

The difficulties appear when the child is introduced to the family table and alimentation. In many families the alimentation is far from a healthy diet, making the continuity of good dietetic habits, which their children had up to that time, difficult ${ }^{(10,11)}$. On the other hand, during this period parents feel more responsible and are more motivated and receptive to following guidelines received from health-care teams ${ }^{(12)}$. A review of the eating habits at this time may help achieve good adherence to a healthy diet by both parents and their children. Parents' food preferences directly influence the eating behaviour of their children. In Spain the Mediterranean diet (MD) has been identified as a healthy dietary pattern ${ }^{(13)}$ since it is part of Spanish culture and is considered one of the healthiest dietary patterns. It has been shown to be a reference model of Western cultures due to its cardioprotective effects ${ }^{(14,15)}$.

Although many intervention studies have been carried out in school settings in children from 4 to 6 years of age, few intervention studies have been performed in relation to dietary habits in children younger than 2 years ${ }^{(9,16)}$.

The aim of the present study was to evaluate the effectiveness of an educational programme on healthy alimentation, carried out in day-care centres and aimed at the parents of children from 1 to 2 years of age, in order to teach them healthy dietary habits for both their children and themselves. With this programme, we hope that parents will improve their own eating habits and will offer their children a healthier pattern to follow.

\section{Methods}

\section{Design}

Multicentre, multidisciplinary, randomized controlled intervention study carried out in the community setting.

\section{Study setting}

The EniM study (nutritional intervention study among children from Mataró) was performed in twelve day-care centres in the city of Mataró (north of Barcelona), including nine public centres and three of the ten existing private centres, with a total of forty-four classrooms of the first cycle of infant education.

\section{Study participants}

Children from 1 to 2 years of age registered in the participating day-care centres and their respective mothers or fathers, according to who was responsible for the alimentation of the child during the school year 2010-2011.

\section{Exclusion criteria}

Children still exclusively breast-feeding at the time of the study, children whose parents were not responsible for their alimentation, children with special diets due to chronic diseases (such as coeliac disease, food intolerances or allergies, inflammatory bowel disease), parents with language difficulties, parents unable to attend the educational workshops and those who did not sign the informed consent.

\section{Randomization}

The unit of randomization was the day-care centre so that the participants of the same day-care centre belonged to the same group, control or intervention. The randomization considered the socio-economic level of the neighbourhood in which the day-care centre was located so that the study groups were comparable with respect to this variable. The sample size of the intervention group was estimated to be larger since more drop outs were foreseen in this group due to the need for its members to attend at least three educational workshops.

\section{Study groups}

At the beginning of the school term, all parents of the children attending the participating day-care centres were invited to informative meetings regarding the study with the use of pamphlets and posters. Both the intervention and the control groups underwent a basal evaluation at the beginning (October 2010) and another at the end of the school year (May 2011). To facilitate the attendance of the parents to the meetings these were made in the school itself, coinciding with the same timetable at which the parents picked up their children. A recreational area was provided for the children while the parents attended the session.

\section{Intervention}

All parents from the day-care centres in the intervention group (IG) were invited to attend four educational workshops on alimentation at the beginning of the study (October-November) and one reminder at 4 months (March). Each theoretical-practical workshop lasted $90 \mathrm{~min}$, was directed by nurses trained in nutrition and was limited to fifteen persons. Workshops' contents are detailed in Table 1. A model of participatory-active education was used, in order to achieve practical skills in addition to nutritional knowledge ${ }^{(17)}$. Cognitive (teaching how to improve diet), emotional (addressing beliefs and attitudes of the participants through discussion and analysis techniques) and skill areas (developing dietary skills) were included. The aim was to incorporate new and better dietary knowledge and to change the habits of the participants. The topics were chosen because they were related to the MD and children diets ${ }^{(13)}$, and taking into account the previous expertise of the investigators regarding nutritional formative intervention in primary health-care centres.

The parents included in the control group (CG) did not receive any education related to nutrition. In order to avoid drop outs, the participants of the CG were invited to a workshop on a subject not related to the study or nutritional education (manipulation and conservation of foods). Attendance was optional. 
Table 1 Description of the workshops. EniM study (nutritional intervention study among children from Mataró), Spain

\begin{tabular}{|c|c|c|}
\hline Workshop & Theoretical content & Practical content \\
\hline 1. Food groups & $\begin{array}{l}\text { - Identify and know the function of: } \\
\circ \text { Fast and slow absorption } \\
\text { carbohydrates } \\
\circ \text { Animal and vegetal proteins } \\
\circ \text { Saturated and unsaturated } \\
\text { lipids }(n-9, n-6 \text { and } n-3) \\
\circ \text { Soluble and insoluble fibres } \\
\text { - Identification of foods with better } \\
\text { nutritional quality } v \text {. worse } \\
\text { nutritional quality }\end{array}$ & $\begin{array}{l}\text { - Game: 'Go to the market'. With the support of educational } \\
\text { material, parents have to choose among different food groups } \\
\text { and explain their characteristics }\end{array}$ \\
\hline 2. Mediterranean diet & $\begin{array}{l}\text { - Definitions of a balanced diet } \\
\text { - Recommended food intake } \\
\text { servings } \\
\text { - Cooking methods } \\
\text { - Recipes and elaboration } \\
\text { - Concept of Mediterranean diet and } \\
\text { its health benefits }\end{array}$ & $\begin{array}{l}\text { - Game: 'Menu of the week'. Participants are divided into groups } \\
\text { of five. Each group must design a balanced and original menu } \\
\text { of the week. They must show their menu to their classmates } \\
\text { and discuss strategies and techniques (cooking, elaboration, } \\
\text { buying, etc.). Participants identify weaknesses and strengths } \\
\text { of each menu. Misconceptions on dietary topics are discussed }\end{array}$ \\
\hline 3. Physical activity. Food labels & $\begin{array}{l}\text { - Types of physical exercise: } \\
\circ \text { Aerobic } \\
\circ \text { Anaerobic } \\
\circ \text { Their health effects } \\
\text { - Identify the ingredients and } \\
\text { nutrients of packaged foods }\end{array}$ & $\begin{array}{l}\text { - How to know the theoretical maximum heart rate and how to } \\
\text { apply this to the intensity of leisure-time physical activity } \\
\text { - 'Card game': Participants analyse ingredients and energy, fat, } \\
\text { carbohydrates, fibres and salt from different photographs of } \\
\text { labels of packaged foods }\end{array}$ \\
\hline $\begin{array}{l}\text { 4. Progressive introduction of food } \\
\text { groups to children }\end{array}$ & $\begin{array}{l}\text { - Strategies and skills to provide a } \\
\text { balanced diet and to prevent } \\
\text { neophobia }\end{array}$ & $\begin{array}{l}\text { - Attractive dishes: colourful, funny, to capture the attention of } \\
\text { children } \\
\text { - Prevent monotonous diets }\end{array}$ \\
\hline 5. Reminder & $\begin{array}{l}\text { - Reminder of the workshops } \\
\text { - Questions and doubts }\end{array}$ & $\begin{array}{l}\text { - Focal groups } \\
\text { - Share knowledge and experiences }\end{array}$ \\
\hline
\end{tabular}

\section{Data collection and study dynamics}

The same variables were collected from the parents (who also answered the questions referring to their children) in both groups, including sociodemographic, anthropometric (measured by the investigators) and nutritional information. In order to determine the variability in the diet from different points of view and also to avoid and compensate for the limitations of each tool, different validated questionnaires were used: two short questionnaires to evaluate MD and an FFQ to calculate macro- and micronutrients.

Parent variables were: age; sex; smoking; alcohol intake; physical activity (using the International Physical Activity Questionnaire $^{(18)}$ ); level of education; marital status; number of children; occupation; weight; height; BMI; knowledge of the MD (using eleven simple questions) ${ }^{(19)}$; adherence to the MD (using the Fourteen-Item Test ${ }^{(20)}$ : low adherence ( $0-5$ points), medium (6-9 points), high (10-14 points)); and an FFQ validated in Spain ${ }^{(21,22)}$ consisting of an individual self-administered questionnaire with a closed list of ninety-two foods, specifying the frequency and standard measures of average servings during the last year, taking into account the seasonality of each food.

Child variables were: weight; height; months of breastfeeding; adherence to the MD (using the Kidmed test ${ }^{(23)}$ : scores $<4$ points considered low adherence and scores of 9-12 points as high adherence); and the FFQ adapted from that of the adults, with seventy-eight items, adapting the size of the servings and only taking into account consumption during the last 6 months ${ }^{(24)}$.

\section{Elaboration of the results}

The daily grams of each food consumed were computed from the FFQ, and the mean daily quantities of macro- and micronutrients ingested by each participant were obtained using software based on the Spanish food composition tables $^{(25)}$. With these values, the Mediterranean Diet Quality Index (MDQI) of the parents was estimated adopting the Gerber criteria ${ }^{(26,27)}$, which consider the proportion of SFA in relation to energy and intakes of cholesterol, meat, olive oil, fish, cereals, vegetables and fruit. The result was expressed as a percentage (with a value $>50 \%$ corresponding to an acceptable MD).

The daily consumption of the food groups was quantified using the quantities proposed by the guidelines of the Spanish Society of Community Nutrition (SENC) ${ }^{13}$ to define a serving in adults. The calculation of servings in children was based on the quantities proposed by the Spanish Society of Paediatrics (S-PED) for children from 0 to 3 years of age ${ }^{(28,29)}$.

\section{Statistical analysis}

The profiles of participants in the study groups were compared with the $\chi^{2}$ test (categorical variables) and Student's $t$ test (continuous variables), using the Fisher 
exact and Mann-Whitney test, respectively, according to the distribution of the data. Likewise, we compared the characteristics of the participants who completed the whole intervention and those who dropped out. The changes observed at the end of the course compared with baseline variables were studied using paired tests. In addition, these changes were analysed by linear regression adjusted by the basal value of the dependent variable to control for a possible effect of regression to the mean, using the group assigned to each parent or child as an explanatory variable. All comparisons were bilateral with significance at 5\%. The statistical software package Stata version 13 was used for the statistical analyses.

\section{Results}

The percentage of participation was $35.5 \%$, including a total of 206 children and 195 parents. The number of parents and children did not coincide because of the inclusion of twins and triplets. Fourteen children and fourteen parents were excluded because they fulfilled at least one exclusion criterion once recruited. Of the parents randomized to the IG only sixty-seven (65\%) attended three or more workshops, with the remaining parents considered drop outs. The reasons for not attending the workshops were mainly difficulties in family timetables and illness of the children. Six parents (and their seven children) in the CG did not do the final questionnaire because of having moved outside the city. Finally, a total of seventy-five children and sixty-seven parents were included in the IG and seventy-four children and seventy-two parents in the CG (Fig. 1). None of the variables studied showed significant basal differences among the parents and children who completed the study and those who did not, except that the parents who completed the study were older (35 v. 33 years, respectively) and had a higher level of education $(31 \%$ of the parents with primary studies finished the study $v$. $78 \%$ of those with a university education).

The basal characteristics of both the parents and the children who completed the study were similar in the two study groups (Tables 2 and 3). Mothers were mainly in charge of the food of their children ( $88 \%$ ) and the mean age of the parents was 35 years at the time of completing the first questionnaire. Fifty-five per cent had university studies and all had one to three children. The participating children had a mean age of 1.3 years at recruitment, with $43 \%$ being girls.

No differences were found between the two groups of parents at baseline with regard to dietary habits and the consumption of foods and nutrients (Table 4). Among the children, a greater number of servings of legumes and butter/margarine/industrial bakery products were found in the CG and greater vitamin D intake was observed in the IG (Table 5). Parent adherence to the MD was $56.4 \%$ measured with the MDQI and 6.5 points according to the
Fourteen-Item Test, while the score of the children was $7 \cdot 7$ points with the Kidmed test. Ten per cent continued supplementing the alimentation with breast milk at the time of entry in the study.

At the end of follow-up the parents in the IG showed an improvement in MD adherence compared with those in the CG, with an increase of 5.78 points in the Gerber index (Table 6). An increase, albeit not significant, of 0.58 points was also found in the Fourteen-Item Test in the IG compared with the CG. The quantities of vegetables and garden produce, olive oil and fish consumed increased while consumption of the butter/margarine/industrial bakery products group diminished in the IG compared with the CG. An analogous increase in the intake of vitamins $C$ and D was observed in the IG compared with the CG. Adherence to the MD also improved in the children in the IG, with an increase of 0.60 points more in the Kidmed test in the IG compared with the CG (Table 7). On the other hand, no significant differences were observed between the two groups of children with respect to food and nutrient intakes, except for a reduction in vitamin D consumption in both groups, being greater in the IG. All these results were maintained on adjustment for the basal values of the foods and nutrients analysed, although this time the consumption of sweets, snacks and soft drinks reduced significantly more among the parents in the IG $(-0.35$ servings $/ \mathrm{d}, P=0.05)$ and the decrease observed in vitamin $\mathrm{D}$ intake in children lost statistical significance $(-0.77 \mu \mathrm{g} / \mathrm{d}$, $P=0 \cdot 18)$.

\section{Discussion}

The present study evaluated the effectiveness of an educational programme on alimentation of children aged 1-2 years, aimed at the acquisition of healthy eating habits among the parents of the participating children. With respect to the parents, on completion of the first-year evaluation, the IG showed a significant improvement in MD adherence and the consumption of vegetables, fish, olive oil and vitamins $\mathrm{C}$ and D improved significantly compared with the CG, with a subsequent decrease in the intake of butter, margarine and industrial bakery products. With regard to children the changes were less evident, and only an improvement in adherence to the MD was observed.

\section{Evaluation of the results of the basal questionnaire in the parents}

It is of note that almost $90 \%$ of the participating parents had a secondary or higher education. In comparison with parents with a higher educational level, those with a lower level more frequently dropped out of the study prior to completion by not attending the minimum number of workshops required. On the other hand, we do not know the sociodemographic profile of the parents who had been invited to participate but did not attend the first interview. 


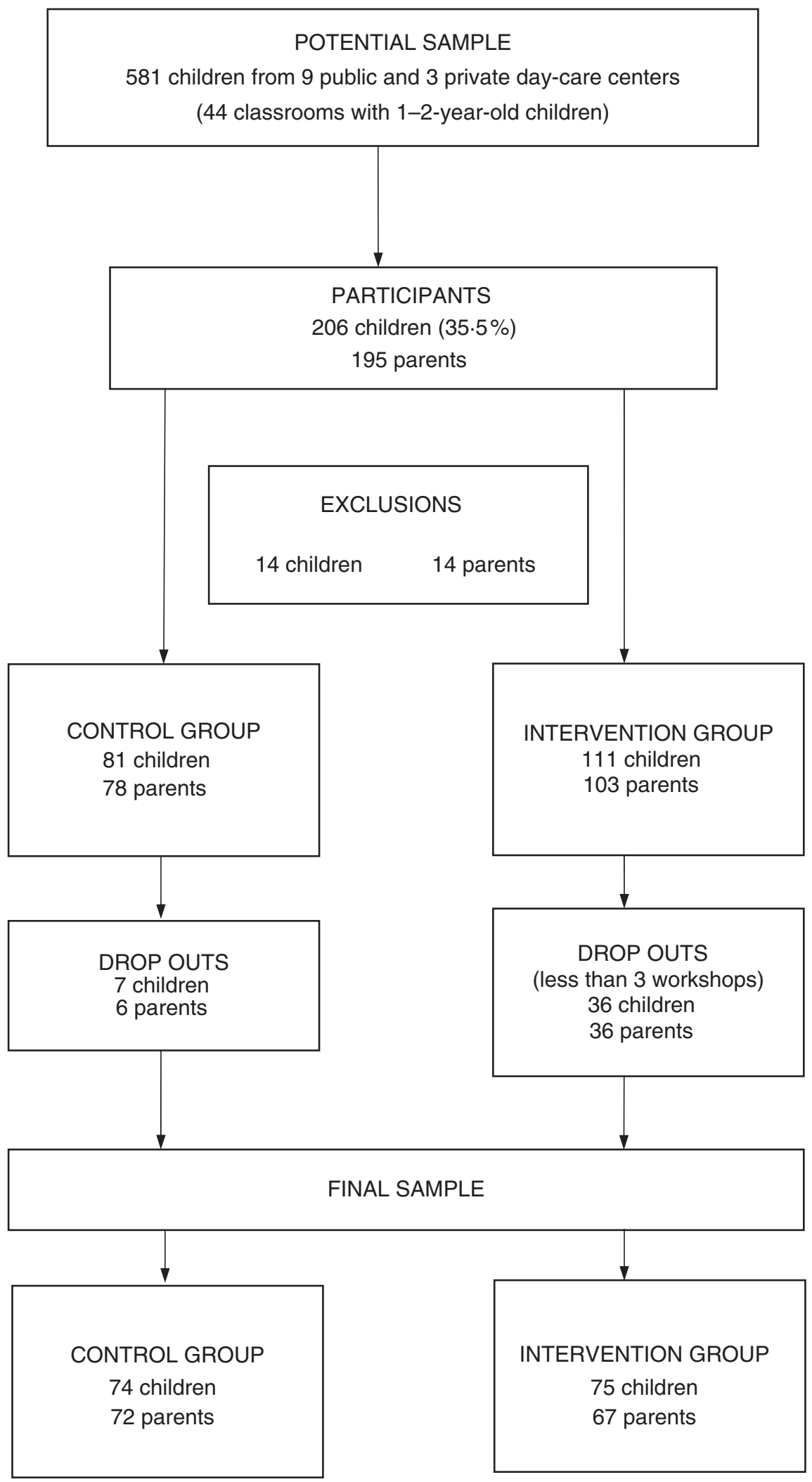

Fig. 1 Flowchart of the study

Nevertheless, the educational level of those who completed the study is in agreement with the Health Survey of Catalonia in which $89 \%$ of the parents of children in day-care centres have secondary or higher educational levels ${ }^{(30)}$ and may correspond to the fact that day-care centres are not free in our region. The number of 
Table 2 Comparison of the baseline characteristics of parents in the control group (CG) and the intervention group (IG). EniM study (nutritional intervention study among children from Mataró), Spain

\begin{tabular}{|c|c|c|c|c|c|c|c|}
\hline & \multicolumn{2}{|c|}{$\mathrm{CG}(n 72)$} & \multicolumn{2}{|c|}{ IG $(n 67)$} & \multicolumn{2}{|c|}{ Total $(n$ 139) } & \multirow[b]{2}{*}{$P$} \\
\hline & $n$ or Mean & $\%$ or SD & $n$ or Mean & $\%$ or $\mathrm{SD}$ & $n$ or Mean & $\%$ or SD & \\
\hline Sex & & & & & & & 0.15 \\
\hline Men & 11 & 15 & 5 & 7 & 16 & 12 & \\
\hline Women & 61 & 85 & 62 & 93 & 123 & 88 & \\
\hline Age (years), mean and SD & $35 \cdot 0$ & 4.0 & 35.0 & 3.4 & $35 \cdot 0$ & 3.7 & 0.92 \\
\hline Educational level & & & & & & & 0.15 \\
\hline Primary & 10 & 14 & 4 & 6 & 14 & 10 & \\
\hline Secondary & 27 & 38 & 21 & 31 & 48 & 35 & \\
\hline University & 35 & 49 & 42 & 63 & 77 & 55 & \\
\hline With partner & 69 & 96 & 65 & 97 & 134 & 96 & 0.71 \\
\hline Number of children, mean and SD & 1.4 & 0.6 & 1.5 & 0.6 & 1.4 & 0.6 & 0.26 \\
\hline Number of persons in the household, mean and SD & $3 \cdot 3$ & 0.7 & 3.4 & 0.6 & 3.4 & 0.7 & 0.31 \\
\hline Smoker & 9 & 13 & 11 & 16 & 20 & 14 & 0.51 \\
\hline BMI $\left(\mathrm{kg} / \mathrm{m}^{2}\right)$, mean and SD & 23.9 & 4.0 & $24 \cdot 0$ & $4 \cdot 1$ & 24.0 & 4.0 & 0.80 \\
\hline Physical activity according to IPAQ & 32 & 44 & 28 & 42 & 60 & 43 & 0.31 \\
\hline Low & 7 & 10 & 11 & 16 & 18 & 13 & \\
\hline Moderate & 46 & 64 & 44 & 66 & 90 & 65 & \\
\hline High & 19 & 26 & 12 & 18 & 31 & 22 & \\
\hline Knowledge of Mediterranean diet, mean and SD* & $6 \cdot 4$ & 2.9 & 6.5 & 2.4 & 6.4 & $2 \cdot 7$ & 0.77 \\
\hline
\end{tabular}

*Knowledge of the Mediterranean diet: from -11 (no knowledge) to 11 (total knowledge).

Table 3 Comparison of the baseline characteristics of children in the control group (CG) and the intervention group (IG). EniM study (nutritional intervention study among children from Mataró), Spain

\begin{tabular}{|c|c|c|c|c|c|c|c|}
\hline & \multicolumn{2}{|c|}{ CG $(n 74)$} & \multicolumn{2}{|c|}{ IG $(n 75)$} & \multicolumn{2}{|c|}{ Total (n 149) } & \multirow[b]{2}{*}{$P$} \\
\hline & $n$ or Mean & $\%$ or SD & $n$ or Mean & $\%$ or SD & $n$ or Mean & $\%$ or SD & \\
\hline Sex & & & & & & & 0.16 \\
\hline Boy & 38 & 51 & 47 & 63 & 85 & 57 & \\
\hline Girl & 36 & 49 & 28 & 37 & 64 & 43 & \\
\hline Age (years), mean and SD & 1.4 & 0.3 & 1.3 & 0.3 & 1.3 & 0.3 & 0.46 \\
\hline Weight $(\mathrm{kg})$, mean and SD & $11 \cdot 1$ & 1.5 & $10 \cdot 7$ & 1.5 & $10 \cdot 9$ & 1.5 & 0.09 \\
\hline Height $(\mathrm{cm})$, mean and SD & 81.2 & 4.9 & $80 \cdot 1$ & $6 \cdot 4$ & $80 \cdot 7$ & 5.7 & 0.30 \\
\hline
\end{tabular}

children and the mean age of the mother at her first childbirth (32 years) coincide with the situation in our country.

Among the parents, $27 \%$ were overweight and $8 \%$ obese, being similar values to those reported for the Spanish population ${ }^{(31)}$. The basal results of the nutritional assessment of the parents agree with those of recent studies showing a distancing from adequate nutritional parameters according to the MD pattern ${ }^{(32)}$, despite an acceptable knowledge of the MD with a mean score of 6.4 points on a scale from -11 to 11 .

In the Fourteen-Item Test our participants showed a mean adherence to the MD of 6.5 points, being comparable to that described by Domínguez et al. in the SUN (Seguimiento Universidad de Navarra) study ${ }^{(33)}$ in a cohort similar to ours. Moreover, the subjects in the study by Domínguez et al. had a mean age of 38 years and the participants presenting greater adherence to the MD were those who were older, coinciding with our study $(6 \cdot 8$ points in participants aged $\geq 35$ years $v .6 \cdot 1$ in those aged $<35$ years, $P=0.02)$. The average score for this test in the Predimed study $^{(34)}$ carried out in Spain in people aged $55-80$ years was 8.6 points. A similar situation has also been reported in other studies in the Mediterranean area ${ }^{(26)}$, and it is considered that adherence to the MD is deteriorating in our society and that our older population remains as the reservoir of knowledge related to a healthy diet. Among the parameters analysed with the test, it is of note that only $16 \%$ of the participants fulfilled the criterion of consumption of legumes and $14 \%$ that of fruit, $37 \%$ olive oil and $42 \%$ raw and cooked vegetables. In addition, $27 \%$ fulfilled the criterion of limiting the intake of red meat and sausages.

The result of the MDQI was $56.4 \%$, which is considered good adherence to the MD. This value is somewhat higher than that reported by Bondía-Pons et al. ${ }^{(26)}$ (45\% in subjects aged $<30$ years and $51 \%$ in those aged $31-50$ years), perhaps due to the composition of our population including a high proportion of participants with university education in whom better compliance to healthy alimentation was observed (the MDQI improved from $49 \%$ to $58 \%$ in our study on comparing primary $v$. university education, $P=0.06$ ), similar to what was reported by Bammann et al. ${ }^{(35)}$.

The consumption of foods with regard to the recommendations of the SENC (Fig. 2) showed good intakes of vegetables, garden produce and fish. On the other hand, the recommended quantities of cereals, potatoes, fruit, olive 
Table 4 Comparison of the nutritional characteristics of the parents in the control group (CG) and the intervention group (IG) at baseline. EniM study (nutritional intervention study among children from Mataró), Spain

\begin{tabular}{|c|c|c|c|c|c|c|c|}
\hline & \multicolumn{2}{|c|}{$\mathrm{CG}(n 72)$} & \multicolumn{2}{|c|}{ IG $(n 67)$} & \multicolumn{2}{|c|}{ Total (n 139) } & \multirow[b]{2}{*}{$P$} \\
\hline & Mean & SD & Mean & SD & Mean & SD & \\
\hline \multicolumn{8}{|l|}{ Adherence to the Mediterranean diet } \\
\hline Fourteen-Item Test ${ }^{\star}$ & $6 \cdot 6$ & 1.9 & $6 \cdot 4$ & $1 \cdot 7$ & 6.5 & $1 \cdot 8$ & 0.50 \\
\hline Gerber index (MDQI)† & $56 \cdot 5$ & $13 \cdot 3$ & $56 \cdot 3$ & $14 \cdot 0$ & $56 \cdot 4$ & 13.6 & 0.91 \\
\hline \multicolumn{8}{|l|}{ Food consumption (servings/d) $\ddagger$} \\
\hline Potatoes, rice, bread, wholewheat bread and pasta & 2.9 & 1.5 & $3 \cdot 1$ & 1.5 & 3.0 & 1.5 & 0.36 \\
\hline Vegetables and garden produce & 2.5 & 1.4 & $2 \cdot 7$ & 1.5 & $2 \cdot 6$ & 1.4 & 0.64 \\
\hline Fruit & $2 \cdot 3$ & $2 \cdot 3$ & $2 \cdot 1$ & $1 \cdot 2$ & $2 \cdot 2$ & $1 \cdot 8$ & 0.39 \\
\hline Olive oil & $2 \cdot 1$ & 1.6 & $1 \cdot 8$ & $1 \cdot 1$ & $2 \cdot 0$ & 1.4 & 0.22 \\
\hline Milk and derivatives & $2 \cdot 1$ & 1.2 & $2 \cdot 2$ & 1.4 & $2 \cdot 2$ & 1.3 & 0.67 \\
\hline Fish & 0.6 & 0.3 & 0.6 & 0.3 & $\overline{0.6}$ & 0.3 & 0.29 \\
\hline Lean meat & 0.6 & 0.4 & 0.5 & 0.3 & 0.6 & 0.3 & 0.50 \\
\hline Poultry & 0.4 & 0.2 & 0.5 & 0.2 & 0.4 & 0.2 & 0.26 \\
\hline Eggs & 0.3 & 0.1 & 0.3 & 0.2 & 0.3 & 0.2 & 0.40 \\
\hline Legumes & 0.3 & 0.1 & 0.3 & $0 \cdot 1$ & 0.3 & 0.1 & 0.95 \\
\hline Nuts & 0.2 & 0.2 & 0.2 & 0.3 & 0.2 & 0.3 & 0.45 \\
\hline Sausages and fatty meats & 0.7 & 0.4 & 0.8 & 0.4 & 0.8 & 0.4 & 0.70 \\
\hline Sweets, snacks, soft drinks & 1.5 & 1.3 & 1.5 & 1.3 & 1.5 & 1.3 & 0.88 \\
\hline Butter, margarine and industrial bakery products & 0.8 & 0.8 & 0.9 & 0.8 & 0.8 & 0.8 & 0.89 \\
\hline Drinking-water & 4.4 & $2 \cdot 2$ & $4 \cdot 2$ & $2 \cdot 0$ & $4 \cdot 3$ & $2 \cdot 1$ & 0.54 \\
\hline Beer or wine & 0.6 & 1.5 & $0 . \overline{3}$ & 0.5 & 0.4 & $1 \cdot 2$ & 0.17 \\
\hline \multicolumn{8}{|l|}{ Daily intakes of macro- and micronutrients } \\
\hline Energy $(\mathrm{kJ})$ & 9275 & 2544 & 9012 & 2640 & 9150 & 2586 & 0.55 \\
\hline Saturated fats $(\mathrm{g})$ & $30 \cdot 1$ & $10 \cdot 1$ & $29 \cdot 6$ & $12 \cdot 3$ & 29.9 & $11 \cdot 1$ & 0.78 \\
\hline Monounsaturated fats $(\mathrm{g})$ & $40 \cdot 3$ & $14 \cdot 6$ & $38 \cdot 0$ & 13.5 & $39 \cdot 2$ & $14 \cdot 1$ & 0.34 \\
\hline Polyunsaturated fats $(\mathrm{g})$ & $16 \cdot 6$ & 7.4 & $15 \cdot 1$ & $6 \cdot 2$ & $15 \cdot \overline{8}$ & 6.8 & 0.20 \\
\hline Sugars (g) & $112 \cdot 2$ & $49 \cdot 6$ & $108 \cdot 2$ & 45.5 & $110 \cdot 2$ & $47 \cdot 6$ & 0.62 \\
\hline Polysaccharides $(\mathrm{g})$ & 118.6 & 43.5 & 121.9 & $44 \cdot 2$ & 120.2 & 43.7 & 0.66 \\
\hline Alcohol $(\mathrm{g})$ & 4.6 & $12 \cdot 3$ & 2.4 & 4.1 & 3.5 & $9 \cdot 3$ & 0.17 \\
\hline Vegetable protein $(\mathrm{g})$ & $32 \cdot 6$ & $11 \cdot 2$ & $32 \cdot 0$ & $10 \cdot 4$ & $32 \cdot 3$ & $10 \cdot 8$ & 0.75 \\
\hline Animal protein $(\mathrm{g})$ & 69.4 & $20 \cdot 8$ & 69.5 & 18.9 & 69.5 & $19 \cdot 8$ & 0.99 \\
\hline Cholesterol (mg) & $320 \cdot 2$ & 118.9 & 318.6 & 93.4 & 319.4 & $107 \cdot 0$ & 0.93 \\
\hline $\mathrm{Ca}(\mathrm{mg})$ & $1076 \cdot 6$ & 416.9 & 1096.5 & 464.4 & $1086 \cdot 2$ & 438.9 & 0.79 \\
\hline Vitamin D (ergocalciferol and cholecalciferol; $\mu \mathrm{g}$ ) & 3.7 & 1.9 & 3.2 & 1.9 & 3.5 & 1.9 & 0.20 \\
\hline Vitamin C (ascorbic and dehydroascorbic acid; $\mathrm{mg}$ ) & $212 \cdot 7$ & 138.7 & 201.6 & $97 \cdot 3$ & $207 \cdot 4$ & $120 \cdot 2$ & 0.59 \\
\hline
\end{tabular}

MDQI, Mediterranean Diet Quality Index.

${ }^{*}$ The possible score ranges from 0 (null adherence) to 14 (total adherence).

$\dagger$ Expressed as \%. $0=$ null adherence and $100=$ maximum adherence. Adherence $>50 \%$ considered good. $\ddagger$ Groups of foods and servings according to the Spanish Society of Community Nutrition (SENC).

oil, nuts, lactic products and water were not consumed, and the consumption of sausages and fatty meats, sweets, snacks, soft drinks and butter, margarine and industrial bakery products was found to be excessive, being comparable to other studies in the general population.

With regard to the recommendations of the SENC for macro- and micronutrients, we found an excess of total energy consumed as proteins (19\% v. 15\%), an excess of saturated fats $(12 \% v .8 \%)$ and a deficit of carbohydrates ( $42 \% v .50 \%$ ). Among the micronutrients the daily intake of cholesterol was higher than the recommended maximum value $(300 \mathrm{mg})$, with a deficit in vitamin $\mathrm{D}$ intake (3.5 v. $5 \mu \mathrm{g}$ ), while $\mathrm{Ca}$ and vitamin $\mathrm{C}$ intakes were correct.

\section{Evaluation of the results of the basal questionnaire in the children}

The result of the Kidmed test was $7 \cdot 7$ points, indicating medium-good adherence to the MD. This value agrees with that estimated in the study protocol, which supposes that the diet is more correct in children 1-2 years of age since the parents receive and follow the recommendations directly from the team of paediatricians. However, it should be taken into account that in the first questionnaire applied at baseline the children were 1.3 years of age and had not yet incorporated all food groups into their diet, and this may thereby affect the reliability of the test. No significant differences were observed in the responses to each item among the study groups, except in the item 'breakfast with lactic' (97\% IG, 85\% CG). Nevertheless, the differences of the servings of lactic products consumed were not very great.

The numbers of servings of the different food groups were similar to the recommendations of the S-PED standardized for children from 1 to 2 years of age ${ }^{(28,29)}$ in regard to vegetables, garden produce, fish, meats and legumes, with the consumption of fruit, cereals and tubers, olive oil, lactic products and water being scarce. Nuts were not eaten at this early age. A worrisome excess of butter and industrial bakery product intake at this age was observed (Fig. 3). The CG showed a higher consumption of legumes and 
Table 5 Comparison of the nutritional characteristics of the children in the control group (CG) and the intervention group (IG) at baseline. EniM study (nutritional intervention study among children from Mataró), Spain

\begin{tabular}{|c|c|c|c|c|c|c|c|}
\hline & \multicolumn{2}{|c|}{ CG $(n 74)$} & \multicolumn{2}{|c|}{ IG $(n 75)$} & \multicolumn{2}{|c|}{ Total ( $n$ 149) } & \multirow[b]{2}{*}{$P$} \\
\hline & Mean or $n$ & SD or $\%$ & Mean or $n$ & SD or $\%$ & Mean or $n$ & SD or $\%$ & \\
\hline \multicolumn{8}{|l|}{ Breast-feeding } \\
\hline Months breast-feeding & $6 \cdot 4$ & $5 \cdot 7$ & $5 \cdot 1$ & 4.8 & $5 \cdot 7$ & $5 \cdot 3$ & 0.15 \\
\hline Continues breast-feeding ( $n, \%)$ & 8 & 11 & 7 & 9 & 15 & 10 & 0.76 \\
\hline Adherence to the Mediterranean diet (Kidmed test) & 7.5 & 1.6 & $7 \cdot 8$ & 1.5 & $7 \cdot 7$ & 1.6 & 0.23 \\
\hline \multicolumn{8}{|l|}{ Food consumption (servings/d)† } \\
\hline Potatoes, rice and pasta & 1.5 & $0 \cdot 8$ & 1.6 & 1.0 & 1.5 & 0.9 & 0.85 \\
\hline Bread, wholewheat bread and cereals & $1 \cdot 1$ & 0.8 & 0.9 & 0.8 & 1.0 & 0.8 & 0.23 \\
\hline Vegetables and garden produce & 1.7 & $1 \cdot 1$ & $2 \cdot 1$ & 1.3 & 1.9 & $1 \cdot 2$ & 0.08 \\
\hline Fruit & $2 \cdot 0$ & 1.4 & 1.9 & 1.0 & 1.9 & 1.2 & 0.43 \\
\hline Olive oil & 1.0 & 0.7 & 1.0 & 0.6 & 1.0 & 0.7 & 0.43 \\
\hline Milk and derivatives & 1.3 & $1 \cdot 1$ & 1.5 & 1.4 & 1.4 & 1.3 & 0.43 \\
\hline Fish & 0.5 & 0.4 & 0.5 & 0.2 & 0.5 & 0.3 & 0.44 \\
\hline Lean meat & 0.4 & 0.3 & 0.5 & 0.3 & 0.4 & 0.3 & 0.73 \\
\hline Poultry & 0.4 & 0.3 & 0.5 & 0.5 & 0.5 & 0.4 & 0.38 \\
\hline Eggs & 0.2 & 0.2 & 0.2 & 0.2 & 0.2 & 0.2 & 0.72 \\
\hline Legumes & 0.3 & 0.2 & 0.2 & 0.2 & 0.3 & 0.2 & 0.03 \\
\hline Nuts & 0.0 & $0 \cdot 1$ & 0.0 & 0.1 & 0.0 & 0.1 & 1.00 \\
\hline Sausages and fatty meats & 0.4 & 0.4 & 0.4 & 0.4 & 0.4 & 0.4 & 0.85 \\
\hline Sweets, snacks, soft drinks & 0.4 & $1 \cdot 1$ & 0.4 & 0.8 & 0.4 & 1.0 & 0.63 \\
\hline Butter, margarine and industrial bakery products & 1.2 & 1.0 & 0.8 & $0 \cdot 8$ & 1.0 & 0.9 & 0.03 \\
\hline Drinking-water & $2 \cdot 6$ & 1.8 & $2 \cdot 1$ & 1.7 & 2.4 & 1.8 & 0.08 \\
\hline \multicolumn{8}{|l|}{ Daily intakes of macro- and micronutrients } \\
\hline Energy $(\mathrm{kJ})$ & 5213 & 1711 & 5284 & 1966 & 5247 & 1837 & 0.81 \\
\hline Saturated fats $(\mathrm{g})$ & $14 \cdot 7$ & 8.7 & $15 \cdot 0$ & 11.9 & 14.9 & $10 \cdot 4$ & 0.86 \\
\hline Monounsaturated fats $(\mathrm{g})$ & $21 \cdot 7$ & $8 \cdot 6$ & $22 \cdot 8$ & $10 \cdot 8$ & $22 \cdot 3$ & $9 \cdot 7$ & 0.49 \\
\hline Polyunsaturated fats $(\mathrm{g})$ & $6 \cdot 3$ & $4 \cdot 0$ & $5 \cdot 3$ & 3.0 & $5 \cdot 8$ & 3.5 & 0.09 \\
\hline Sugars $(g)$ & 88.7 & $31 \cdot 7$ & 89.6 & $32 \cdot 2$ & $89 \cdot 1$ & 31.9 & 0.86 \\
\hline Polysaccharides $(\mathrm{g})$ & $70 \cdot 8$ & 28.4 & 73.1 & $25 \cdot 4$ & 71.9 & $26 \cdot 9$ & 0.59 \\
\hline Vegetable protein $(\mathrm{g})$ & $15 \cdot 8$ & 7.5 & 14.2 & 4.9 & $15 \cdot 0$ & $6 \cdot 3$ & 0.14 \\
\hline Animal protein $(\mathrm{g})$ & 33.2 & 14.9 & $35 \cdot 4$ & $18 \cdot 9$ & $34 \cdot 3$ & $17 \cdot 0$ & 0.42 \\
\hline Cholesterol (mg) & 144.9 & 80.5 & 153.4 & $100 \cdot 0$ & $149 \cdot 2$ & $90 \cdot 6$ & 0.57 \\
\hline $\mathrm{Ca}(\mathrm{mg})$ & 839.7 & $336 \cdot 2$ & $906 \cdot 2$ & 414.7 & $872 \cdot 9$ & 377.7 & 0.29 \\
\hline Vitamin D (ergocalciferol and cholecalciferol; $\mu \mathrm{g}$ ) & $5 \cdot 3$ & 3.5 & $6 \cdot 7$ & 3.3 & $6 \cdot 0$ & 3.5 & 0.01 \\
\hline Vitamin C (ascorbic and dehydroascorbic acid; mg) & $145 \cdot 3$ & $67 \cdot 6$ & 153.8 & $56 \cdot 0$ & 149.5 & $62 \cdot 0$ & 0.41 \\
\hline
\end{tabular}

*The possible score ranges from -4 (null adherence) to 12 (total adherence).

†Groups of foods and servings according to the Spanish Society of Paediatrics (S-PED).

butter/margarine/industrial bakery products. However, this difference was not observed in either the Kidmed test or on studying the macro- and micronutrients, in which no significant differences were found in the vegetable or animal protein values or in the proportions of the different types of fats or the carbohydrate fractions.

Energy intake was equivalent between the two groups and coincided with the recommendations of the paediatric guidelines. The proportion of carbohydrates in relation to energy (51\%) was correct, although an excess of simple sugars was observed (28\%). Proteins were at the upper threshold of the norm (16\% of energy). Vitamin D and C levels were correct although vitamin $\mathrm{D}$ intake was higher in the children in the IG. This may be due to an earlier initiation of bottle feeding with formula milk enriched with vitamin $\mathrm{D}^{(36)}$ in the IG compared with the CG in which there was a trend to more prolonged breast-feeding.

Ten per cent of the children were breast-feeding at the beginning of the study, with a mean breast-feeding period up to that time, excluding those who had never been breast-fed (23\%), of 7.4 months. These data differ from the recent National Survey on Breastfeeding Habits in Spain $^{(37)}$ in which only $11.3 \%$ had not been breast-fed.

\section{Evaluation of the intervention in the parents}

Our data demonstrate a slight, albeit consistent, improvement in the IG which is shown in the different tools used: being significant in the MDQI ( 5.78 points of improvement), the Fourteen-Item Test ( 0.58 points $)$ and in the assessment by servings, with an increase in vegetable, olive oil and fish intake and a reduction in the butter/margarine/industrial bakery product group. We also observed an increase, albeit not statistically significant, in the consumption of fruit and drinking-water and a reduction in the sweets/snacks/soft drinks group. However, no improvement was found in the potatoes/rice/bread group or in the sausages/fatty meats group. With regard to the level of micronutrients, a significant increase in the intake of vitamins $\mathrm{D}$ and $\mathrm{C}$ was observed in the IG in relation to the increase in the consumption of fish, fruit and vegetables.

The healthy effects of the MD on mortality, CVD, cancer, obesity and type 2 diabetes are well known ${ }^{(38,39)}$, 
Table 6 Comparison of changes in adherence to the Mediterranean diet and food and nutrient intakes of the parents between the control group (CG) and the intervention group (IG) following the intervention. EniM study (nutritional intervention study among children from Mataró), Spain

\begin{tabular}{|c|c|c|c|c|c|}
\hline & \multicolumn{2}{|c|}{ CG $(n 72)$} & \multicolumn{2}{|c|}{ IG $(n 67)$} & \multirow[b]{2}{*}{$P$} \\
\hline & Mean & SD & Mean & SD & \\
\hline \multicolumn{6}{|l|}{ Adherence to the Mediterranean diet } \\
\hline Fourteen-Item Test ${ }^{*}$ & -0.22 & 1.72 & 0.36 & 2.00 & 0.07 \\
\hline Gerber index (MDQI)† & 0.40 & 12.04 & $6 \cdot 18$ & $12 \cdot 30$ & 0.01 \\
\hline \multicolumn{6}{|l|}{ Food consumption (servings/d) $\ddagger$} \\
\hline Potatoes, rice, bread, wholewheat bread and pasta & $-0 \cdot 13$ & 1.68 & 0.01 & 1.75 & 0.64 \\
\hline Vegetables and garden produce & 0.04 & 1.27 & 0.58 & 1.35 & 0.02 \\
\hline Fruit & -0.15 & 2.06 & 0.37 & $1 \cdot 18$ & 0.07 \\
\hline Olive oil & -0.23 & 1.34 & 0.45 & 1.48 & 0.01 \\
\hline Milk and derivatives & -0.03 & 0.98 & -0.05 & $1 \cdot 27$ & 0.92 \\
\hline Fish & -0.02 & 0.27 & 0.13 & 0.33 & 0.01 \\
\hline Lean meat & -0.01 & 0.35 & -0.01 & 0.27 & 0.99 \\
\hline Poultry & -0.01 & 0.23 & 0.01 & 0.21 & 0.55 \\
\hline Eggs & 0.03 & 0.21 & 0.03 & 0.20 & 0.94 \\
\hline Legumes & 0.05 & 0.29 & 0.02 & 0.17 & 0.58 \\
\hline Nuts & 0.00 & 0.26 & 0.02 & 0.28 & 0.68 \\
\hline Sausages and fatty meats & 0.03 & 0.49 & 0.05 & 0.50 & 0.87 \\
\hline Sweets, snacks, soft drinks & 0.01 & 1.21 & -0.32 & 1.09 & 0.09 \\
\hline Butter, margarine and industrial bakery products & 0.02 & 0.88 & -0.25 & 0.75 & 0.05 \\
\hline Drinking-water & 0.13 & 1.74 & 0.75 & 2.03 & 0.06 \\
\hline Beer or wine & -0.19 & 1.38 & 0.00 & 0.41 & 0.28 \\
\hline \multicolumn{6}{|l|}{ Daily intakes of macro- and micronutrients } \\
\hline Energy (kJ) & -264 & 2556 & 163 & 2318 & 0.30 \\
\hline Saturated fats $(\mathrm{g})$ & -0.90 & $10 \cdot 47$ & -1.28 & 11.15 & 0.84 \\
\hline Monounsaturated fats $(\mathrm{g})$ & -1.90 & 13.81 & $2 \cdot 23$ & 14.99 & 0.09 \\
\hline Polyunsaturated fats $(\mathrm{g})$ & -0.63 & 6.58 & 0.48 & $5 \cdot 15$ & 0.27 \\
\hline Sugars $(g)$ & -1.35 & 53.62 & 1.48 & $32 \cdot 35$ & 0.71 \\
\hline Polysaccharides (g) & $-2 \cdot 13$ & 44.90 & -0.72 & 51.96 & 0.86 \\
\hline Alcohol (g) & -1.52 & $10 \cdot 72$ & -0.05 & 3.31 & 0.28 \\
\hline Vegetable protein $(\mathrm{g})$ & -0.03 & $10 \cdot 02$ & 1.84 & $10 \cdot 22$ & 0.28 \\
\hline Animal protein $(\mathrm{g})$ & -1.21 & 18.88 & 3.44 & 18.53 & 0.15 \\
\hline Cholesterol (mg) & 1.94 & $121 \cdot 16$ & 12.07 & 94.93 & 0.59 \\
\hline $\mathrm{Ca}(\mathrm{mg})$ & -14.56 & 368.55 & 32.69 & 395.74 & 0.47 \\
\hline Vitamin D (ergocalciferol and cholecalciferol; $\mu \mathrm{g}$ ) & 0.01 & 2.22 & 0.98 & 2.28 & 0.01 \\
\hline Vitamin C (ascorbic and dehydroascorbic acid; $\mathrm{mg}$ ) & $-16 \cdot 02$ & 111.83 & 29.62 & 72.56 & 0.01 \\
\hline
\end{tabular}

MDQI, Mediterranean Diet Quality Index.

${ }^{*}$ The possible score ranges from 0 (null adherence) to 14 (total adherence).

†Expressed as \%. $0=$ null adherence and $100=$ maximum adherence. Adherence $>50 \%$ considered good. ¥Groups of foods and servings according to the Spanish Society of Community Nutrition (SENC).

independently of the different indices used ${ }^{(40)}$ to quantify the grade of adherence to the MD. The meta-analysis by Sofi et $a l^{(41)}$ found that a 2-point improvement in the Fourteen-Item Index reduced mortality by $8 \%$, cardiovascular risk by $10 \%$ and neoplasms by $4 \%$. In the Spanish study by Martínez-González et al. ${ }^{(42)}$ a 1-point increase in the index was associated with an $18 \%$ reduction in the relative risk of myocardial infarction. The SUN study ${ }^{(43)}$, carried out among a university educated population with a mean age of 38 years and followed for 6.8 years, found for each 2-point increase in the Fourteen-Item Index that the hazard ratio of death was 0.72 . In the Predimed study, which included persons 55-80 years of age without previous CVD disease but with a high cardiovascular risk, the initial index was 8.6. After $4 \cdot 8$ years the index of the intervention group improved from 1.4 to 1.8 points compared with the control group, and a reduction was observed in the absolute risk of three major cardiovascular events per 1000 person-years, with an approximately $30 \%$ reduction in the relative risk ${ }^{(44)}$. As stated by Arós and Estruch ${ }^{(45)}$, few drugs are able to reduce the incidence of major cardiovascular complications by $30 \%$ as achieved in an intervention with the MD. In our group, the improvement of 0.58 points after the intervention may be considered modest. However, as shown, greater adherence to the MD may play an important role in the reduction of cardiovascular risk and in the improvement of general health status.

Our sample included parents with a high educational level, and according to other studies it has been shown that the level of education of the parents influences the consumption of a healthier diet. In our study the results obtained one year after the intervention showed an improvement in adherence to the MD of more than $5 \%$. Taking into account that changes in habits are difficult to achieve in parents with acceptable adherence to the MD, we consider our results to be satisfactory and comparable to those of other studies reporting a positive impact following an educational intervention. 
Table 7 Comparison of changes in adherence to the Mediterranean diet and food and nutrient intakes of the children between the control group (CG) and the intervention group (IG) following the intervention. EniM study (nutritional intervention study among children from Mataró), Spain

\begin{tabular}{|c|c|c|c|c|c|}
\hline & \multicolumn{2}{|c|}{ CG $(n 74)$} & \multicolumn{2}{|c|}{ IG $(n 75)$} & \multirow[b]{2}{*}{$P$} \\
\hline & Mean or $n$ & SD or $\%$ & Mean or $n$ & SD or $\%$ & \\
\hline \multicolumn{6}{|l|}{ Breast-feeding } \\
\hline Months breast-feeding & $7 \cdot 0$ & $6 \cdot 6$ & $5 \cdot 8$ & $6 \cdot 3$ & 0.24 \\
\hline Has discontinued breast-feeding $(n, \%)$ & 3 & 38 & 1 & 14 & 0.31 \\
\hline Adherence to the Mediterranean diet ${ }^{\star}$ (Kidmed test) & 0.47 & 1.65 & 1.07 & 1.46 & 0.02 \\
\hline \multicolumn{6}{|l|}{ Food consumption (servings/d) $\dagger$} \\
\hline Potatoes, rice and pasta & $0 \cdot 10$ & 0.91 & 0.09 & $1 \cdot 12$ & 0.92 \\
\hline Bread, wholewheat bread and cereals & 0.27 & 1.08 & 0.39 & 1.00 & 0.48 \\
\hline Vegetables and garden produce & -0.26 & 1.51 & -0.20 & 1.40 & 0.83 \\
\hline Fruit & -0.19 & 1.23 & 0.07 & 0.88 & 0.14 \\
\hline Olive oil & $0 \cdot 18$ & 0.77 & $0 \cdot 14$ & 0.77 & 0.77 \\
\hline Milk and derivatives & 1.46 & 1.51 & 1.45 & 1.85 & 0.98 \\
\hline Fish & 0.06 & 0.44 & 0.14 & 0.34 & 0.17 \\
\hline Lean meat & -0.04 & 0.38 & -0.04 & 0.32 & 0.92 \\
\hline Poultry & -0.03 & 0.33 & -0.13 & 0.52 & 0.14 \\
\hline Eggs & 0.05 & 0.20 & 0.06 & $0 \cdot 18$ & 0.73 \\
\hline Legumes & 0.09 & 0.39 & 0.21 & 0.36 & 0.06 \\
\hline Nuts & 0.02 & 0.09 & 0.02 & $0 \cdot 10$ & 0.86 \\
\hline Sausages and fatty meats & 0.20 & 0.41 & $0 \cdot 19$ & 0.42 & 0.80 \\
\hline Sweets, snacks, soft drinks & 0.29 & 1.25 & 0.38 & 0.85 & 0.61 \\
\hline Butter, margarine and industrial bakery products & -0.14 & 1.07 & $0 \cdot 12$ & 0.98 & 0.12 \\
\hline Drinking-water & 0.86 & 1.78 & 0.79 & 1.95 & 0.82 \\
\hline \multicolumn{6}{|l|}{ Daily intakes of macro- and micronutrients } \\
\hline Energy $(\mathrm{kJ})$ & 699 & 1837 & 510 & 1657 & 0.52 \\
\hline Saturated fats $(\mathrm{g})$ & $7 \cdot 21$ & 9.22 & 7.65 & 9.94 & 0.78 \\
\hline Monounsaturated fats $(\mathrm{g})$ & 2.91 & 8.66 & 1.88 & 8.37 & 0.46 \\
\hline Polyunsaturated fats $(\mathrm{g})$ & 1.36 & 4.29 & 1.37 & 2.43 & 1.00 \\
\hline Sugars $(\mathrm{g})$ & 3.33 & $39 \cdot 29$ & 0.51 & 29.93 & 0.63 \\
\hline Polysaccharides $(\mathrm{g})$ & $1 \cdot 12$ & $32 \cdot 15$ & -5.84 & $27 \cdot 61$ & 0.16 \\
\hline Vegetable protein $(\mathrm{g})$ & 0.67 & $8 \cdot 27$ & 1.29 & $5 \cdot 36$ & 0.60 \\
\hline Animal protein $(\mathrm{g})$ & 8.42 & $16 \cdot 28$ & 7.38 & 17.04 & 0.71 \\
\hline Cholesterol (mg) & $60 \cdot 22$ & $86 \cdot 19$ & $56 \cdot 92$ & $89 \cdot 15$ & 0.82 \\
\hline $\mathrm{Ca}(\mathrm{mg})$ & $178 \cdot 30$ & 474.80 & 121.45 & $405 \cdot 34$ & 0.44 \\
\hline Vitamin D (ergocalciferol and cholecalciferol; $\mu \mathrm{g})$ & -1.49 & 4.19 & $-3 \cdot 23$ & $4 \cdot 10$ & 0.01 \\
\hline Vitamin C (ascorbic and dehydroascorbic acid: $\mathrm{mg}$ ) & $-24 \cdot 16$ & $72 \cdot 32$ & -26.66 & 48.63 & 0.81 \\
\hline
\end{tabular}

*The possible score ranges from -4 (null adherence) to 12 (total adherence).

†Groups of foods and servings according to the Spanish Society of Paediatrics (S-PED).

\section{Evaluation of the intervention in the children}

In the Kidmed test on adherence to the MD, the IG improved by 0.6 points compared with the CG. On the other hand, no significant differences were observed in the consumption of foods between the two groups. Nor were significant differences found between the two groups in macro- and micronutrient intakes, except in vitamin D intake. The reduction found in the IG disappeared on adjustment for the basal values of vitamin D intake. Logically the quantities consumed in both groups rose due to the increase in the age of the children. The incorporation of new food groups in the period from 1 to 2 years of age may induce the lack of differences in the foods consumed. A new study of their eating habits after one more year might then reflect this possible effect of the intervention as suggested by the results of the Kidmed test.

Llargués et al. ${ }^{(46)}$ performed a 2-year educational intervention on healthy alimentation and physical activity in Spanish children from 5 to 6 years of age. At the end of the intervention a significant improvement was found in fruit consumption in the IG, with a decrease in fish intake in the CG.

\section{Final evaluation}

The dietary interventions collected in the Summary Report of the $\mathrm{WHO}^{(47,48)}$ in 2009 presented similar values of effectiveness as those in our study. In a systematic review of interventions aimed a promoting the consumption of fruit and vegetables, Pomerleau et al. ${ }^{(49)}$ described an increase from $0 \cdot 1$ to 1.4 servings/d in healthy adults. On the other hand, Monasta et al. ${ }^{(50)}$ reviewed seventeen randomized trials on the prevention of obesity in preschool children. Changes in diet and physical activity were found in some cases; however, no final effects were observed in the reduction of obesity and overweight which, according to the authors, could have been due to methodological defects. In a recent study by Céspedes et $a l .{ }^{(51)}$ among children aged 3-5 years in Bogotá, an educational intervention involving children, parents and teachers aimed at improving the knowledge, attitudes and habits related to healthy eating and active lifestyle achieved an improvement of approximately $5.5 \%$ in the children and parents.

Our study shows that indices measuring adherence to the MD and the consumption of healthy foods such as 


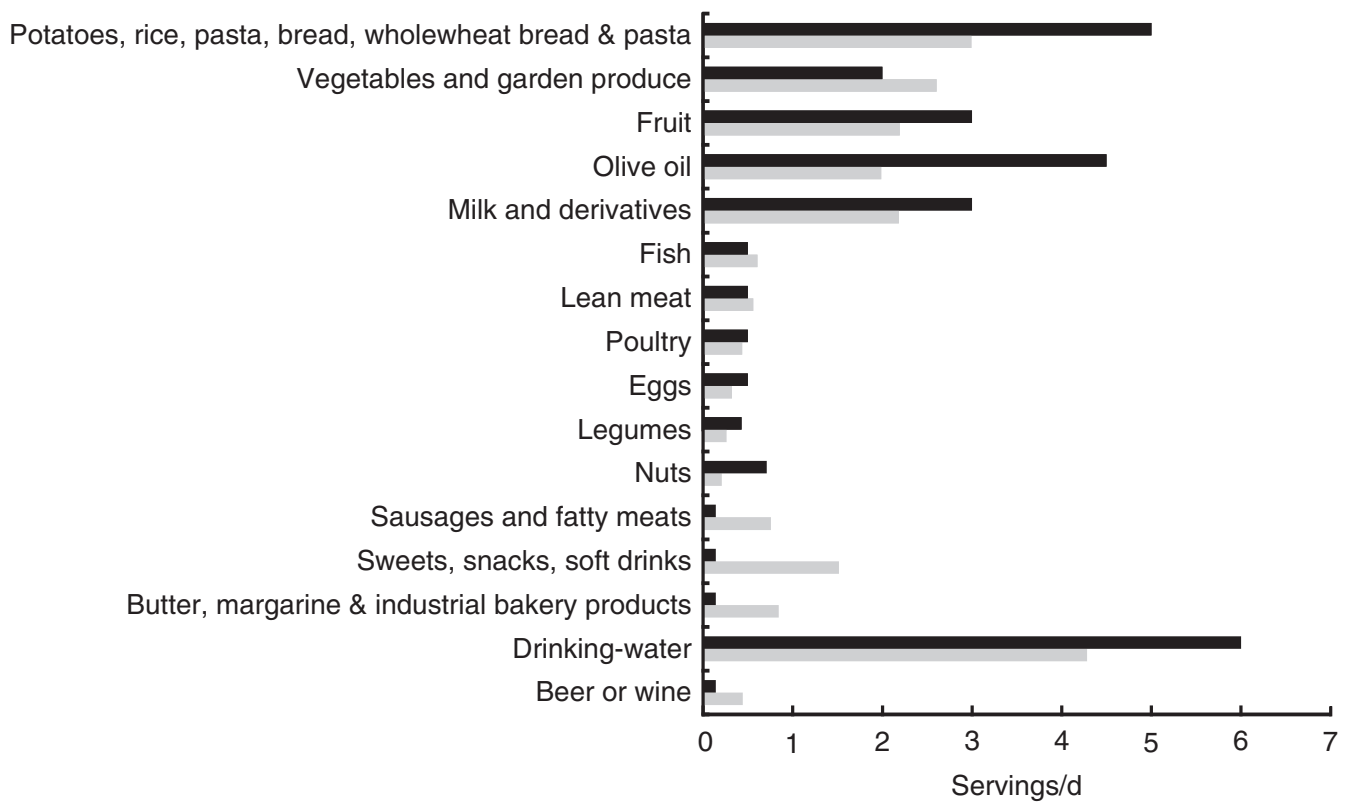

Fig. 2 Daily servings of foods consumed by parents participating in the EniM study (nutritional intervention study among children from Mataró; ) and servings recommended by the Spanish Society of Community Nutrition (SENC;

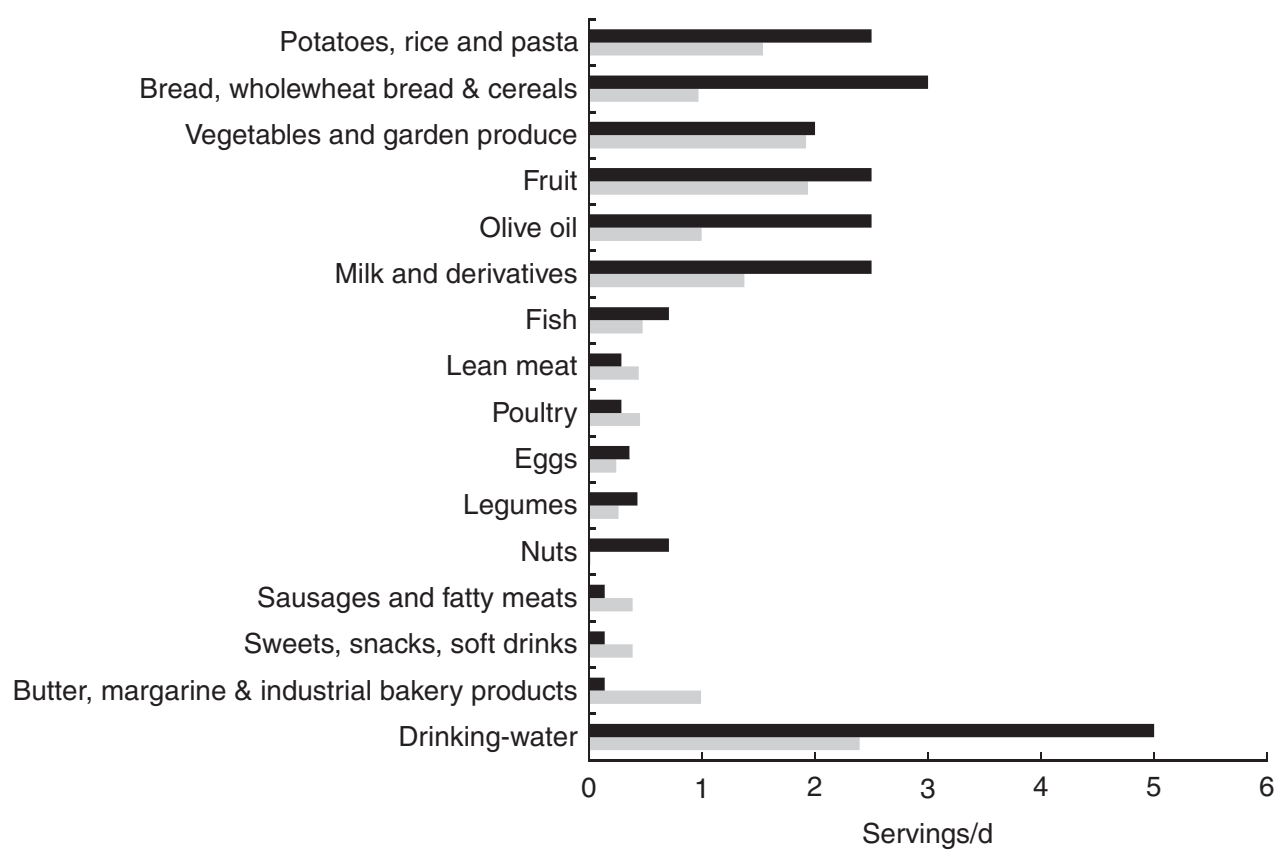

Fig. 3 Daily servings of food consumed by children participating in the EniM study (nutritional intervention study among children from Mataró; ) and servings recommended by the Spanish Society of Paediatrics (S-PED;

fruit, vegetables, fish and olive oil improved in the parents in the IG. These improvements of about $5 \%$, albeit modest, are statistically significant. Indeed, a $5 \%$ improvement is usually considered important in an intervention on lifestyle and diet. On the other hand, differences were found among the children only in the Kidmed test, with no significant changes in the study of nutrients and servings. These changes in the group of children should therefore be evaluated with caution and a follow-up into the second year has been proposed to allow better assessment. There may not have been sufficient time for the changes that the adults had introduced into their diet to have had any repercussion in the diet of their children.

More importance was given to the changes in the parents, who are those with more aspects requiring improvement. Considering the hypothesis that the diet of the children is initially correct, what is of interest is whether this adequacy is maintained and does not decline over time. 
The results of the present study demonstrate the importance of an improvement in actions based in the school and the community to promote healthy eating habits in children and young people.

\section{Study limitations}

With the randomization of the schools we have avoided a possible contamination among parents in the IG to the CG. The design of the study does not allow masking, but the statistical analysis was blinded (the analyst did not know which school each group belonged to). The parents who did not participate in the first questionnaire could have been different from those who did participate, although no data are available regarding the non-participants. Participation was strongly promoted with emphasis on the importance of the study related to the alimentation of their children. In regard to the workshops and questionnaires, the availability of the investigative team was very flexible. Parents attending workshops were reminded of the meeting by a telephone call as well as posters in the schools. Nevertheless, $35 \%$ did not finish the study, those with a lower educational level being less likely to complete the study. In any case, there were no nutritional differences among those completing the intervention and those who did not. It should be taken into account that at these ages the children have illnesses which temporarily impede attendance at school and may thereby compromise the availability of the parents.

A validated FFQ for children 1-2 years of age is not currently available; therefore we adapted one according to the nutritional guidelines for children of age 1-3 years. Likewise, the Kidmed test was developed for use in children over 2 years of age, so that the data of the first test allow comparison of the two study groups but do not infer evaluations with respect to the quality of the diet. In addition, although we made a great effort to collect precise dietetic data, any measurement of the diet has inherent limitations of precision due to the bias of notification, memory or measurement errors. However, we used more than one collection and assessment tool and our data were comparable to the mean Spanish diet.

It is also important to point out that the participants in our study had specific socio-economic and cultural characteristics (high educational level, employment) which may limit the generalization of our findings.

\section{Applicability}

It should be remarked that the intervention undertaken may feasibly be carried out from primary-care centres in which an important part of the tasks of nursing staff is aimed at the community. Parent attendance was facilitated by having the sessions in the day-care centres. Clearly not all the parents in the day-care centres were involved and thus new approaches are needed to diffuse the information to the parents unable to attend. On the other hand, strategies to reach the parents of children not attending day-care centres are also required. In addition, it is important to follow the participants for another year in order to determine whether the effect of the intervention is maintained.

\section{Conclusions}

An educational intervention in parents during the key period of the incorporation of 1-2-year-old children to the family table has been shown to be feasible from primary care in our setting. The results of the present study showed significant increases in the adherence of parents to the MD which should lead to future improvement in different indicators of health and cardiovascular risk. This improvement is expected to be reflected in the diet of their children. In order to achieve better assessment of these results we propose a follow-up of these children at 3 years of age.

\section{Acknowledgements}

Acknowledgements: This study received logistic support from the Primary Care Centers of Mataró La Riera and Ronda Prim (Institut Català de la Salut), from the Institut Universitari d'Investigació en Atenció Primària Jordi Gol (IDIAP) and from the IME (Institut Municipal d'Educació) of the City Hall of Mataró, with valuable help from Ascensión Yuste Arnal, educational assistant and coordinator of the management teams of the day-care centres. The authors would also like to thank the following people for their collaboration: Anna Ferrer Romà and Silvia Bernal de Barbarà, nurses in family medicine and paediatrics; Tamara Jiménez Pascua; general practitioner; Trinidad Escoda Pinyol, paediatrician; and Carmen Ferrer Svoboda, professor of the Faculty of Health Care Sciences, Human Nutrition and Dietetics, Blanquerna, Universitat Ramón Llull (Barcelona). They would like to give special thanks to the following municipal children's day-care centres for their collaboration: Cerdanyola, Elna, Els Garrofers, Els Menuts, La Llàntia, La Riereta, Les Figueretes, Rocafonda, Tabalet and the private centres Peques, Sant Jordi and GEM, which participated in the study, as well as the parents for their enthusiastic acceptance to participate in the study. Financial support: This work was supported by a grant for investigation in nursing from Col-legi Oficial d'Infermeria de Barcelona, 2009 (grant number PR-5001/09); Primer Premio Nacional de Investigación en Enfermería, 2009, from Hospital Universitario Marqués de Valdecilla; and a grant for investigation in nursing from Acadèmia de Ciències Mèdiques de Catalunya i Balears, filial Maresme, 2010. The funders had no role in the design, analysis or writing of this article. Conflict of interest: None. Authorship: M.R.-S., J.R.-C. and J.S.-T. formulated the research question and carried out the study; M.R.-S., J.R.-C., J.S.-T. and G.P. designed the study; G.P. and A.D. analysed the data; and M.R.-S., J.R.-C., J.S.-T., G.P. and A.D. wrote the article. 
All authors have participated in the preparation of the manuscript and accept the present version of the text. Ethics of human subject participation: This study was conducted according to the guidelines laid down in the Declaration of Helsinki and all procedures involving human subjects/patients were approved by the Ethics Committee of the IDIAP Jordi Gol. Written informed consent was obtained from all participants.

\section{References}

1. Toledano E, Aznar S, Cortés O et al. (2007) Prevención de la obesidad infantil y juvenil. In $1^{a}$ Conferencia de Prevención y Promoción de la Salud en la Práctica Clínica en España, p. 44. Madrid: Semfyc Ediciones.

2. De Onis M, Blössner M \& Borghi E (2010) Global prevalence and trends of overweight and obesity among preschool children. Am J Clin Nutr 92, 1257-1264.

3. Kelly T, Yang W, Chen C-S et al. (2008) Global burden of obesity in 2005 and projections to 2030. Int J Obes (Lond) 32, 1431-1437.

4. Pérez-Farinós N, López-Sobaler AM, Dal Re MÁ et al. (2013) The ALADINO study: a national study of prevalence of overweight and obesity in Spanish children in 2011. Biomed Res Int 2013, 163687.

5. Lakshman R, Elks CE \& Ong KK (2012) Childhood obesity. Circulation 126, 1770-1779.

6. Wardle J, Carnell S \& Cooke L (2005) Parental control over feeding and children's fruit and vegetable intake: how are they related? J Am Diet Assoc 105, 227-232.

7. Davis MM, McGonagle K, Schoeni RF et al. (2008) Grandparental and parental obesity influences on childhood overweight: implications for primary care practice. $J \mathrm{Am}$ Board Fam Med 21, 549-554.

8. Savage JS, Fisher JO \& Birch LL (2007) Parental influence on eating behavior: conception to adolescence. J Law Med Ethics 35, 22-34.

9. Ciampa PJ, Kumar D, Barkin SL et al. (2010) Interventions aimed at decreasing obesity in children younger than 2 years: a systematic review. Arch Pediatr Adolesc Med $\mathbf{1 6 4}$ 1098-1104

10. Serra Majem L, Ribas Barba L, Salvador Castell G et al. (2007) Tendencias del estado nutricional de la población española: resultados del sistema de monitorización nutricional de Cataluña (1992-2003). Rev Esp Salud Publica 8, 559-570.

11. León-Muñoz LM, Guallar-Castillón P, Graciani A et al. (2012) Adherence to the Mediterranean diet pattern has declined in Spanish adults. J Nutr 142, 1843-1850.

12. Koehler S, Sichert-Hellert W \& Kersting M (2007) Measuring the effects of nutritional counseling on total infant diet in a randomized controlled intervention trial. $J$ Pediatr Gastroenterol Nutr 45, 106-113.

13. Dapcich V, Salvador G, Ribas L et al. (2004) Guía de la alimentación saludable. Sociedad Española de Nutrición Comunitaria. http://aesan.msssi.gob.es/AESAN/docs/docs/ publicaciones_estudios/nutricion/guia_alimentacion.pdf (accessed January 2015).

14. Calañas-Continente A \& Bellido D (2006) Bases científicas de una alimentación saludable. Rev Med Navarra 50, 7-14.

15. Schröder H (2007) Protective mechanisms of the Mediterranean diet in obesity and type 2 diabetes. $J$ Nutr Biochem 18, 149-160.

16. Bluford D AA, Sherry B \& Scanlon KS (2007) Interventions to prevent or treat obesity in preschool children: a review of evaluated programs. Obesity (Silver Spring) 15, 1356-1372.
17. Pérez Jarauta MJ, Echauri Ozcoidi M, Ancizu Irure E et al. (2006) Manual de Educación para la Salud, p. 188. Pamplona: Instituto de Salud Pública Gobierno de Navarra.

18. Craig CL, Marshall AL, Sjöström M et al. (2003) International physical activity questionnaire: 12-country reliability and validity. Med Sci Sports Exerc 35, 1381-1395.

19. Serra-Majem L, Ribas L, Salvador G et al. (2003) Avaluació de l'estat nutricional de la població catalana 2002-2003, p. 61. http://www.aesan.mspsi.gob.es/AESAN/docs/docs/ evaluacion_riesgos/Cataluna.pdf (accessed January 2015).

20. Schröder H, Fitó M, Estruch R et al. (2011) A short screener is valid for assessing Mediterranean diet adherence among older Spanish men and women. J Nutr 141, 1140-1145.

21. Martín-Moreno JM, Boyle P, Gorgojo L et al. (1993) Development and validation of a food frequency questionnaire in Spain. Int J Epidemiol 22, 512-519.

22. Estruch R, Martínez-González MA, Corella D et al. (2006) Effects of a Mediterranean-style diet on cardiovascular risk factors: a randomized trial. Ann Intern Med 145, 1-11.

23. Serra-Majem L, Ribas L, Ngo J et al. (2004) Food, youth and the Mediterranean diet in Spain. Development of KIDMED, Mediterranean Diet Quality Index in children and adolescents. Public Health Nutr 7, 931-935.

24. Roman-Viñas B, Ortiz-Andrellucchi A, Mendez $\mathrm{M}$ et al. (2010) Is the food frequency questionnaire suitable to assess micronutrient intake adequacy for infants, children and adolescents? Matern Child Nutr 6, Suppl. 2, 112-121.

25. Farran A, Zamora R \& Cervera P (2004) Tablas de composición de alimentos del CESNID. Barcelona: McGraw-Hill/ Interamericana de España.

26. Bondia-Pons I, Mayneris-Perxachs J, Serra-Majem L et al. (2010) Diet quality of a population sample from coastal north-east Spain evaluated by a Mediterranean adaptation of the diet quality index (DQI). Public Health Nutr 13, 12-24.

27. Gerber M (2007) Qualitative methods to evaluate Mediterranean diet in adults. Public Health Nutr 9, 147-151.

28. Babio N, Cabezas C, Cabrera D et al. (2009) Recomanacions per a l'alimentació en la primera infancia (de 0 a 3 anys). Direcció General de Salut Pública de la Generalitat de Catalunya. http://canalsalut.gencat.cat/web/.content/home_canal_ salut/ciutadania/vida_saludable/alimentacio/consells generals/documents/recaliprinf.pdf (accessed April 2015).

29. Peña Quintana L, Ros Mar L, González Santana D et al. (2010) Alimentación del preescolar y escolar. In Protocolos Diagnóstico-terapéuticos de Gastroenterología, Hepatología y Nutrición Pediátrica SEGHNP-AEP, 2nd ed., pp. 297-305. Madrid: ERGON.

30. Brugulat Guiteras P, Medina Bustos A \& Mompart Penina A (2013) Enquesta de Salut de Catalunya 2012. Informe dels principals resultats. Direcció General de Planificació i Recerca en Salut, Departament de Salut, Generalitat de Catalunya. http://salutweb.gencat.cat/web/.content/home/el_ departament/estadistiques_sanitaries/enquestes/02_enquesta_ catalunya_continua/documents/arxius/informeesca2012.pdf (accessed January 2015).

31. Aranceta-Bartrina J \& Serra-Majem L (2005) Prevalencia de obesidad en España. Med Clin (Barc) 125, 460-466.

32. Rodríguez-Artalejo F, Graciani A, Guallar-Castillón P et al. (2011) Rationale and methods of the study on nutrition and cardiovascular risk in Spain (ENRICA). Rev Esp Cardiol 64, 876-882.

33. Domínguez LJ, Bes-Rastrollo $\mathrm{M}$, de la Fuente-Arrillaga C et al. (2013) Similar prediction of total mortality, diabetes incidence and cardiovascular events using relative- and absolute-component Mediterranean diet score: the SUN cohort. Nutr Metab Cardiovasc Dis 23, 451-458.

34. Martínez-González MA, García-Arellano A, Toledo E et al. (2012) A 14-item Mediterranean diet assessment tool and obesity indexes among high-risk subjects: the PREDIMED trial. PLoS One 7, e43134. 
35. Bammann K, Gwozdz W, Lanfer A et al. (2013) Socioeconomic factors and childhood overweight in Europe: results from the multi-centre IDEFICS study. Pediatr Obes $\mathbf{8}, 1-12$.

36. Dalmau Serra J \& Moreno Villares J (2011) Leches de crecimiento en la alimentación infantil. Acta Pediatr Esp 69, 373-378.

37. Díaz Gómez M (2013) Encuesta Nacional sobre Hábitos de Lactancia. Global Breastfeeding Summit. http://www.aeped. es/sites/default/files/resumen-presentacion-encuestalmjulio2013_0.pdf (accessed January 2015).

38. Sofi F, Abbate R, Gensini GF et al. (2010) Accruing evidence on benefits of adherence to the Mediterranean diet on health: an updated systematic review and meta-analysis. Am J Clin Nutr 92, 1189-1196.

39. Kastorini C-M, Milionis HJ, Esposito K et al. (2011) The effect of Mediterranean diet on metabolic syndrome and its components: a meta-analysis of 50 studies and 534,906 individuals. J Am Coll Cardiol 57, 1299-1313.

40. Bach A, Serra-Majem L, Carrasco JL et al. (2007) The use of indexes evaluating the adherence to the Mediterranean diet in epidemiological studies: a review. Public Health Nutr 9 , 132-146.

41. Sofi F, Macchi C, Abbate R et al. (2014) Mediterranean diet and health status: an updated meta-analysis and a proposal for a literature-based adherence score. Public Health Nutr 17, 2769-2782.

42. Martínez-González MA, Fernández-Jarne E, Serrano-Martínez M et al. (2004) Development of a short dietary intake questionnaire for the quantitative estimation of adherence to a cardioprotective Mediterranean diet. Eur J Clin Nutr 58, 1550-1552.
43. Martínez-González MA, Guillén-Grima F, De Irala J et al (2012) The Mediterranean diet is associated with a reduction in premature mortality among middle-aged adults. J Nutr 142, 1672-1678.

44. Estruch R, Ros E, Salas-Salvadó J et al. (2013) Primary prevention of cardiovascular disease with a Mediterranean diet. N Engl J Med 368, 1279-1290.

45. Arós F \& Estruch R (2013) Mediterranean diet and cardiovascular prevention. Rev Esp Cardiol 66, 771-774.

46. Llargues E, Franco R, Recasens A et al. (2011) Assessment of a school-based intervention in eating habits and physical activity in school children: the AVall study. $J$ Epidemiol Community Health 65, 896-901.

47. Anderson J, Parker W, Steyn N et al. (2009) Interventions on Diet and Physical Activity: What Works: Summary Report. Geneva: WHO

48. Anderson J, Parker W, Steyn N et al. (2009) Interventions on Diet and Physical Activity: What Works: Evidence Tables. Geneva: WHO.

49. Pomerleau J, Lock K, Knai C et al. (2005) Interventions designed to increase adult fruit and vegetable intake can be effective: a systematic review of the literature. J Nutr $\mathbf{1 3 5}$, 2486-2495.

50. Monasta L, Batty GD, Macaluso A et al. (2011) Interventions for the prevention of overweight and obesity in preschool children: a systematic review of randomized controlled trials. Obes Rev 12, e107-e118.

51. Céspedes J, Briceño G, Farkouh ME et al. (2013) Targeting preschool children to promote cardiovascular health: cluster randomized trial. Am J Med 126, 27-35. 